\title{
Workplace Experience of International Students in Australia
}

\author{
Georgina Baron \\ University of Southern Queensland, Australia \\ Kay Hartwig \\ Griffith University, Australia
}

For the past 3 years over 400,000 international students have enrolled annually to study in higher education contexts in Australia (Australian Government, 2019). The international student enrollments has been valued as Australia's third highest export industry, after coal and iron ore (Grewal \& Blakkarly, 2017). Given the significance of international students, it is important that Australian universities find effective and culturally appropriate ways to support this cohort. One such area needing support is work experience, as many study programs that international students undertake include compulsory or elective courses involving assessed experiences in professional contexts. Degrees such as business, education, engineering, and health, including nursing and psychology, all require students to successfully complete workplace experiences in order to graduate. It is critical that international students are supported before, during, and after workplace components of study. The International Student Barometer indicated that international students desire quality career advice, work experience and subsequently employment as a result of their studies (Garrett, 2014).

This short essay shares brief findings from a federally funded, large-scale project carried out in Australian universities - the Work-placement for International Student Programs (WISP) project. The WISP project aimed to investigate international students' experiences in workplace contexts, but also their preparedness for such experiences. Data was collected from six universities including international student, workplace and university staff interviews; university documents; and international students' assessed reports from their work experience. In addition, a large-scale survey was also distributed across Australia, the findings of which are reported in Barton, Hartwig, and Le (2018). 
Findings from the qualitative data showed that international students face different challenges in work experience as compared with their domestic counterparts. Issues such as language difference, financial difficulties, being away from usual support networks, and cultural difference related to professional skills were identified. We theorized that international students indeed encounter "multisocialization" (Barton, Hartwig, \& Le, 2018), whereby they are expected to socialize into a new country, university context, and workplace environment.

Further, our extensive data showed that many workplace staff have limited capacities in cultural awareness and hence limited diverse approaches to working with, and supporting, international students. In fact, some workplace staff showed hesitation in hosting international students as they perceived them as being "hard work" (Barton, Hartwig, Joseph, \& Podorova, 2017). Conversely, our data showed the success many that international students experience during work placement. For workplace staff who displayed high "ethos" (Knight, 1999), huge benefits in hosting international students were experienced for both parties.

Another major finding was that international students often find reflecting on their practice and consequently putting new practice into place challenging. Of course, this may be an issue for all students; however, our international student participants noted that reflecting on challenges and knowing how to improve action was difficult, particularly if their host was not supportive. Conversely, supportive hosts modeled good practices and worked above and beyond to support international students to success.

Recommendations from the WISP project are outlined in Table 1 below.

\section{Table 1: Recommendations for All Stakeholders in Relation to Work Experience for International Students}

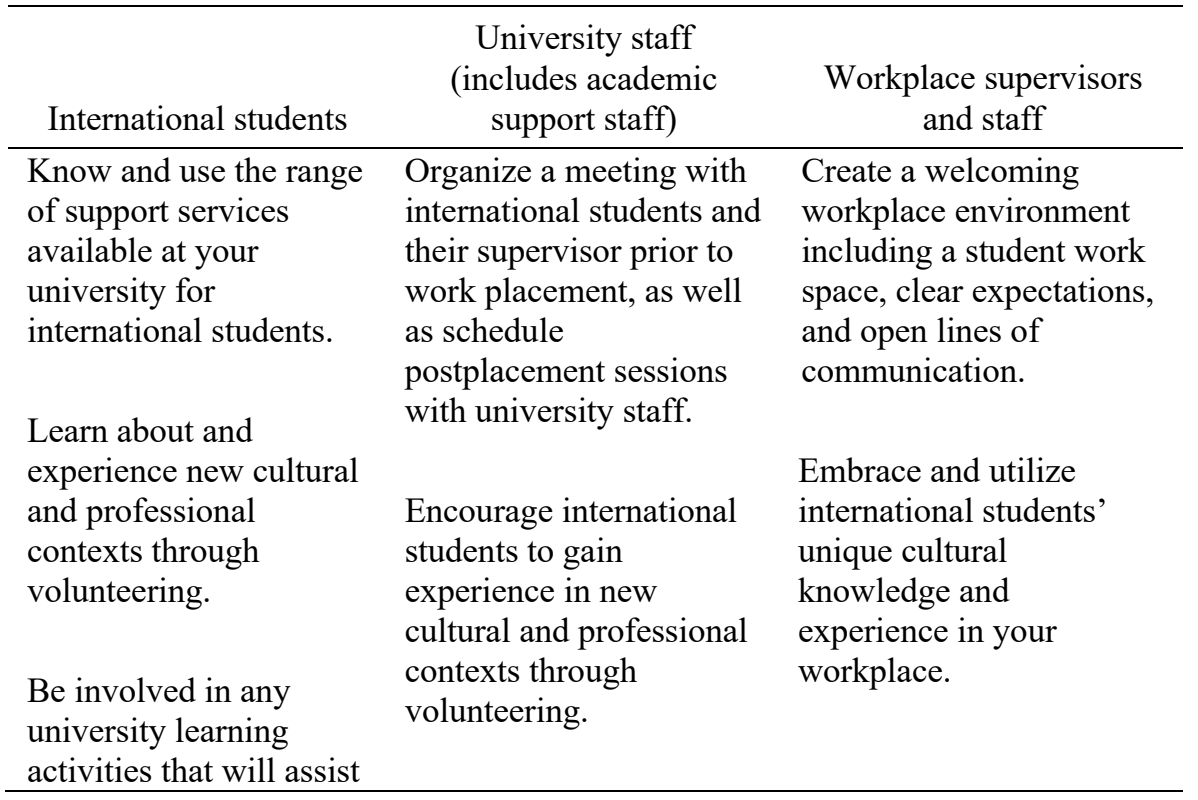




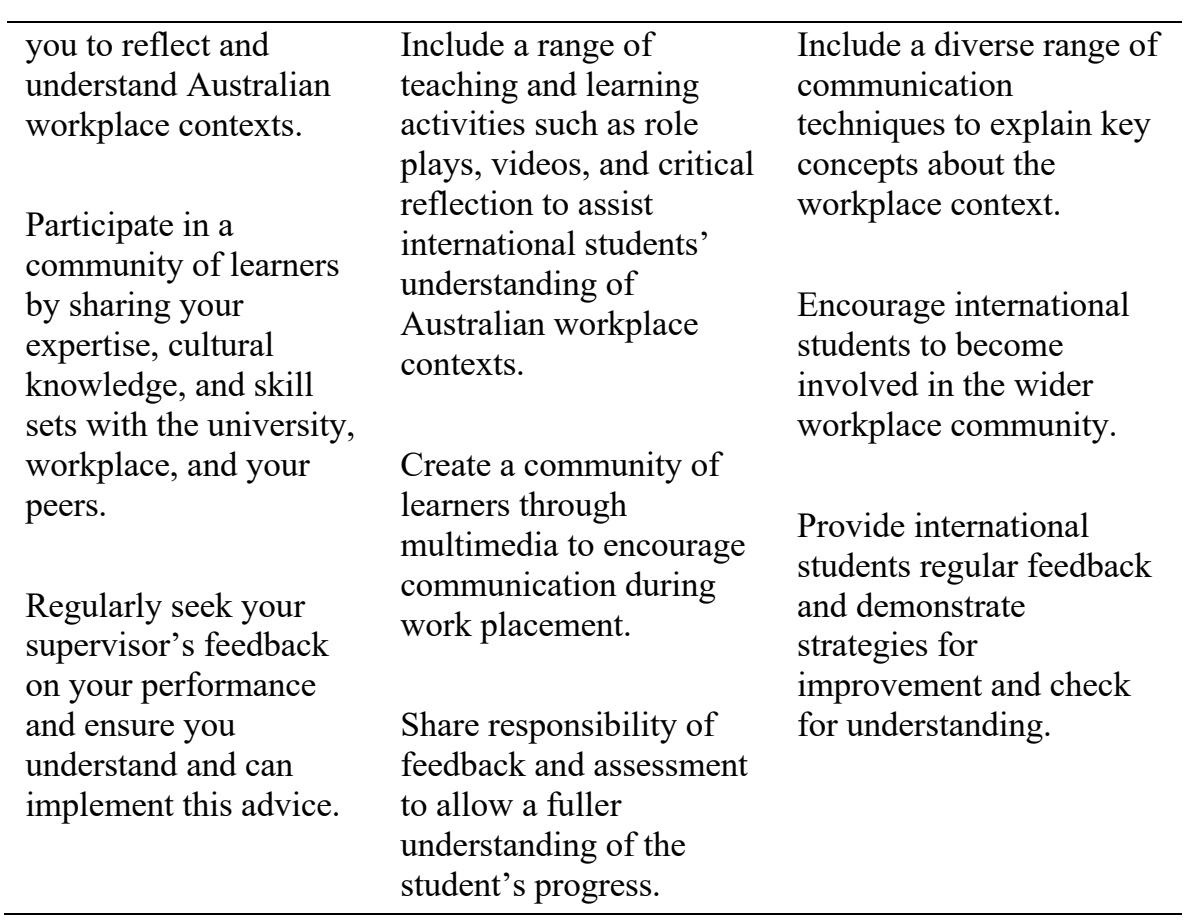

Our project resulted in a conscious focus on positive aspects of international students' workplace experience given the negativity that is often portrayed in the literature. Such a strengths-based approach allowed us to report on ways that worked in supporting both international students and their hosts, ensuring increased employability and reflexive professionals upon graduation. Our studies, so far, have supported international students, university staff and workplace hosts to build positive partnerships in the workplace context, ensuring employability success.

\section{REFERENCES}

Australian Government. (2019). International student data.

https://internationaleducation.gov.au/research/International-Student-

Data/Pages/default.aspx

Barton, G. M., Hartwig, K., Bennett, D., Cain, M., Campbell, M., Ferns, S., Jones, L., Joseph, D., Kavanagh, M., Kelly, A., Larkin, I., O'Connor, E., Podorova, A., Tangen, D., \& Westerveld, M. (2017). Work placement for international students: A model of effective practice. In G. M. Barton \& K. Hartwig (Eds.), Professional learning in the work place for international students: Exploring theory and practice (pp. 13-34). Springer.

Barton, G. M., Hartwig, K., Joseph, D., \& Podorova, A. (2017). Practicum for international students in teacher education programs: An investigation of three university sites through interculturalization and reflection. In G. M. Barton \& 
K. Hartwig (Eds.), Professional learning in the work place for international students: Exploring theory and practice (pp. 129-146). Springer.

Barton, G. M., Hartwig, K., \& Le, A. (2018). International students' perceptions of workplace experiences in Australian study programs: A large-scale survey. Journal of Studies in International Education, 23(2), 248-264. doi: $10.1177 / 1028315318786446$

Garrett, R. (2014). Explaining international student satisfaction: Insights from the International Student Barometer. https://www.i-graduate.org/assets/2014Explaining-Satisfaction.pdf

Grewal, P., \& Blakkarly, J. (2017, March 24). Australia's international student numbers hit new high. SBS News. https://www.sbs.com.au/yourlanguage/node/854062?language=ru

Knight, J. (1999). Internationalization of higher education. In J. Knight, \& H. de Wit (Eds.), Quality and internationalization in higher education (pp. 13-23). OECD.

GEORGINA BARTON, PhD, PFHEA, is a Professor and Associate Head of School - Research in the School of Education at the University of Southern Queensland. Her major research areas are literacy, the arts and cultural diversity. Email: georgina.barton@usq.edu.au

KAY HARTWIG, EdD, is a Senior Lecturer and the Director of Internationalisation in the School of Education and Professional Studies at Griffith University. Her research focuses on music education and internationalisation. Email: k.hartwig@griffith.edu.au 